\title{
Planos de aula de língua portuguesa em plataformas virtuais: das projeções metodológicas às suas inconsistências
}

\author{
Cármen Lúcia Hernandes Agustini ${ }^{1}$ \\ Instituto de Letras e Linguística/Programa de Pós-Graduação em Estudos Linguísticos, \\ Universidade Federal de Uberlândia, Uberlândia, MG, Brasil \\ João de Deus Leite ${ }^{2}$ \\ Colegiado de Letras/Programa de Pós-graduação em Letras: Ensino de Língua e Literatura, Universidade \\ Federal do Tocantins/Câmpus Araguaína, Araguaína, TO, Brasil \\ Ronis A. Gouveia ${ }^{3}$ \\ Universidade Federal do Tocantins/Câmpus Araguaína, Araguaína, TO, Brasil
}

\begin{abstract}
Resumo: Neste artigo, analisamos e problematizamos dois planos de aula de Língua Portuguesa disponibilizados em plataformas virtuais voltadas para o professor. Com base na Análise de Discurso, formulada por Michel Pêcheux, apostamos na perspectiva de que o acesso a essas plataformas, dependendo do uso e das finalidades, pode produzir o efeito de apagamento do lugar de professor. Tais plataformas que disponibilizam materiais prontos, sejam planos de aula, sejam aulas prontas, constroem o perfil de "professor consumidor": aquele que não realiza um trabalho crítico acerca deste material e que deles se vale indiscriminadamente. As análises mostram certos problemas na estruturação dos planos de aula disponibilizados, particularmente na parte metodológica das aulas.
\end{abstract}

Palavras-chave: Planos de Aula; Metodologia; Planejamento; Acontecimento da aula; Discurso.

Title: Portuguese lesson plans on virtual platforms: from methodological procedures to their inconsistencies

Abstract: This article analyzes two Portuguese lesson plans available on virtual platforms aimed at the teacher. Theoretically, the article is based on Discourse Analysis, as conceived by Michel Pêcheux. Depending on how these platforms are used, it is our belief that the access to them can produce an effect of meaning of "erasing" the role of the teacher in the process of teaching Portuguese. This is so because these platforms usually provide teachers with ready materials such as lesson plans. As a result, they end up constructing a profile of a "consumer teacher" who would not be able to be critical on the resources found on the platforms. Consequently, teachers would use them indiscriminately. The analyzes show that the first lesson plan presents fragmented methodological procedures. The second is structurally more consistent. All parts of a class, as predicted in the official curricular parameters, can be identified. Although this plan shows a more consistent

\footnotetext{
${ }^{1}$ Pós-Doutora (Universidade Estadual de Campinas), Universidade Federal de Uberlândia. Orcid: https://orcid.org/0000-0001-5504-3911

E-mail: carmen.agustini@ufu.br

2 Doutor (Universidade Federal de Uberlândia), Universidade Federal do Tocantins. Orcid: https://orcid.org/0000-0002-89189940

E-mail: joaodedeusleite@hotmail.com

${ }^{3}$ Graduado (Universidade Federal do Tocantins). Orcid: https://orcid.org/0000-0002-3406-5297

E-mail: ronisamorim@hotmail.com
} 
structure, there is still a mismatch between the theory underlying the plan and the methodological procedures adopted.

Keywords: Lesson plans; Methodology; Planning; discourse.

\section{Introdução}

Os cursos de licenciatura, em suas diferentes estruturas curriculares, têm por tarefa principal preparar o acadêmico para assumir o espaço de sala de aula como professor. Em função dessa tarefa, são ofertadas diferentes disciplinas pedagógicas, buscando formar o aluno para uma dimensão humanística e didático-pedagógica acerca da sala de aula. Também são ofertadas disciplinas teóricas integrantes à especificidade da área do conhecimento do curso. As diretrizes oficiais propostas pelo Ministério da Educação (MEC) para as licenciaturas orientam que, no âmbito dessas disciplinas teóricas, destine-se uma parte da carga horária para se vislumbrar, de algum modo, o espaço de sala de aula. Trata-se de uma recomendação que busca fomentar a relação entre teoria e prática.

Além das disciplinas pedagógicas e das específicas à área de conhecimento do curso, conta-se, ainda, com as disciplinas de Estágios Supervisionados Curriculares (ESC, doravante) para a formação do futuro professor. Nos ESC, o acadêmico é levado a experienciar o espaço de sala de aula, tendo como interlocutores o professor titular da turma da educação básica, o professor orientador da disciplina de estágio, na universidade, e os próprios alunos da educação básica. Dessa interlocução, o acadêmico precisa construir um lugar de fala, buscando promover uma articulação entre teoria e prática. Agustini e Leite (2016), ao construírem uma relação conceitual entre as teorizações de Foucault e Deleuze (1979) e as de Benveniste (1958; 1970), destacam que essa articulação perpassa o revezamento discursivo, dada a atividade de subjetivação que a enunciação sobre a experiência faz trabalhar.

Nos ESC, além da carga horária teórica, que é realizada na universidade, há a carga horária prática, desenvolvida, pelo acadêmico, na escola campo do estágio. Cada curso de licenciatura configura as disciplinas de estágio, inclusive o quantitativo de carga horária teórica e prática, de modo específico. Nessa carga horária prática, o acadêmico precisa desenvolver atividades de regência em turmas regulares da educação básica. Ele precisa planejar, elaborar e executar aulas, tendo por base os constituintes de um "plano de aula" e as diretrizes oficiais da educação básica específicas da disciplina foco dos ESC.

Do futuro professor, demandam-se competências e habilidades para se articular os diferentes saberes construídos, no curso de graduação, a partir das variadas disciplinas, dada a necessidade de se levar a bom termo a aula em si. Consideraremos a esse "levar a bom termo a aula" a partir da perspectiva de acontecimento discursivo. É esperado que o acadêmico construa condições didático-pedagógicas para que a aula ocorra, considerando as contingências próprias do espaço de sala de aula. 
Uma das contingências que podemos citar é o efeito da aula para o aluno, em termos de aprendizagem, já que, da parte do professor, não é possível haver controle do processo de coconstrução de saber. $\mathrm{O}$ acontecimento passa por tempo subjetivo: tempo do professor e tempo do aluno, marcando um (des)encontro enunciativo. Desse modo, a perspectiva da aula como acontecimento discursivo abre horizonte para pensarmos e questionarmos: a aula foi um acontecimento para quem? Assim, despojamo-nos do lugar de tomá-la como acontecimento a priori, por mais que haja um certo imaginário sobre a sala de aula, homogeneizando as suas relações. Esse imaginário, pela lógica que lhe é própria, ancora-nos no lugar de idealização: recorte de conteúdo, metodologia de ensino, métodos de avaliação. Esse imaginário coloca-nos no lugar da produção, caucionando "pontos de partida". Contudo, ele não garante os "pontos de chegada".

A aula como acontecimento põe em cena, por um lado, as redes de memórias, isto é, os saberes que constituíram o acadêmico em formação (saberes teóricos e didáticopedagógicos) e, por outro, a contingência da aula. No espaço de sala de aula, o acadêmico é levado a assumir uma posição discursivo-enunciativa para sustentar sua relação com seu objeto de trabalho. No caso deste artigo, o objeto em foco é a Língua Portuguesa. Esse modo de sustentação deflagra aspectos da formação do acadêmico.

O acontecimento discursivo pressupõe o fato de que professor e aluno, já na posição de locutores, convertem a língua em discurso para enunciarem. Na condição de locutores, eles agenciam as formas da língua, tornando-as aptas ao emprego e ação. E pressupõe, também, o fato de que professor e aluno, por serem constituídos por uma pluralidade de filiação de sentidos, produzem mo(vi)mentos de (inter)locução que podem (re)atualizar as redes de memórias. Para aludirmos ao foco deste artigo, que é o professor de Língua Portuguesa, seria dizer do modo como este enuncia os saberes relativos a essa língua, não perdendo de vista a constituição teórica e didático-pedagógica que o curso oportunizou, bem como as diretrizes oficiais que buscam balizar tal ensino.

Os cursos de graduação em Letras/Português e os documentos oficiais sobre o ensino e a aprendizagem de Língua Portuguesa engendram uma rede de memória, de modo a estabilizar certos sentidos acerca desse ensino. Do ponto de vista discursivo, há toda uma circunscrição e uma organização que dão formato e lugar a esse ensino. Trata-se de formato e de lugar constituídos historicamente e que, a partir deles, as práticas de sala de aula são idealizadas e geridas. $\mathrm{O}$ acadêmico precisa ser constituído, como professor, a partir dessa rede de memória.

$\mathrm{Na}$ etapa de endereçar-se à escola campo de estágio para vivenciar a prática, o acadêmico em Letras/Português aciona aspectos dessa rede de memória e, por meio deles, lida com o espaço de sala de aula em sua contingência, como estamos considerando neste artigo. É lidar com a aula, para além das projeções imaginárias que são próprias da etapa de planejamento. $\mathrm{O}$ (des)encontro com a contingência, em geral, produz mal-estar. A tentativa errônea de espelhamento entre "planejamento", tendo o plano de aula como dispositivo 
importante, e o acontecimento da aula em si pode gerar grandes desconfortos nos professores em formação.

Um dos aspectos dessa rede de memória a ser construído e, posteriormente, acionado é a elaboração de planos de aula. Na condição de projeção imaginária, a aula precisa ser planejada e concebida em etapas metodológicas, buscando assegurar uma postura professoral em aula. Há o tempo de planejamento da aula, e há um tempo de cumprimento do planejamento no próprio espaço de sala de aula, conforme vimos considerando.

No caso do ensino e da aprendizagem em Língua Portuguesa, esse planejamento necessita de um alinhamento com as diretrizes oficiais, como o fato de as aulas terem de tomar o texto como ponto de partida e de chegada. O texto é concebido como unidade de ensino. Não se recomenda mais um ensino de Língua Portuguesa que se baseie puramente na abordagem gramatical da língua. Desse modo, o ensino de gramática normativa passou a ser ressignificado, tendo o texto como ponto de partida e/ou como ponto de chegada. É preciso ressaltar que a proposição de ressignificar esse ensino não pode ser lida como abandono do ensino de gramática normativa. No espaço educacional brasileiro, houve a constituição e a circulação da discursividade de que esse ensino deveria ser abandonado. Não abordaremos essa temática nesse artigo.

A ressignificação do ensino de gramática normativa contou, por exemplo, com a proposição de um novo eixo estruturador da Língua Portuguesa no âmbito dos documentos oficiais. Trata-se do eixo "Prática de análise linguística". Nos Parâmetros Curriculares Nacionais (PCN), de Língua Portuguesa, esse eixo vincula-se a outros dois, ao propor essa língua como objeto de ensino e de aprendizagem. Os dois eixos são: "Prática de escuta de textos orais e leitura de textos escritos" e "Prática de produção de textos orais e escritos".

Dada a necessidade de alinhamento do planejamento com as diretrizes oficiais, 0 acadêmico precisa estar apto a elaborar um plano de aula em que este tome o texto como ponto de partida e de chegada. Contudo, a seleção e o modo de abordagem do texto tornam-se complexos. Não se configura como tarefa fácil a articulação entre: (1) conteúdos, (2) objetivos (geral e específicos), (3) metodologia (procedimentos) e (4) avaliação, de modo a constituir um efeito de unidade para a aula. Essa articulação perpassa, ainda, a natureza do seguimento de ensino e o próprio ano escolar. A complexidade se acentua, se considerarmos que, nessa etapa de elaboração, o acadêmico precisa conceber a aula como uma futuridade da qual ele não tem controle e, ao mesmo tempo, lidar com a contingência da aula como acontecimento.

A competência e as habilidades de se elaborar um plano de aula com seus constituintes em articulação são um ponto de avaliação relevante no âmbito das disciplinas dos ESC. Como vimos salientando, há uma função a ser exercida pelo professor em formação, no tocante ao planejamento de uma possível aula, e que se mantém após a formação inicial. Essa demanda escolar cria espaço para a existência de uma série de 
plataformas virtuais voltadas para o professor, disponibilizando "planos de aula" prontos. São plataformas virtuais incentivadas pelo governo, a partir de uma política de formação, e outras, fomentadas por portais de notícias, por exemplo.

O acesso a essas plataformas virtuais, a depender do uso e das finalidades, pode produzir o efeito de apagamento do lugar do professor. É que, em muitos casos, volta-se para essas plataformas, com o intuito de tentar reproduzir o plano no espaço de sala de aula. Essas plataformas que disponibilizam materiais prontos, sejam planos de aula, sejam aulas prontas, constroem o perfil de "professor consumidor"; aquele que não realiza um trabalho crítico acerca do material nas plataformas e deles se vale indiscriminadamente.

O trabalho crítico envolve uma formação teórica e didático-pedagógica consistente para se analisar, inclusive, a articulação dos constituintes do "plano de aula". E, nesse caso, para o acontecimento da aula. Não é porque a aula é contingente que não se precisa planejar, elaborar planos de aulas, construindo projeções metodológicas. Ressaltamos que sobre a futuridade da aula não há garantias, mas é preciso planejá-la.

Diante da problematização que apresentamos anteriormente, orientar-nos-emos a partir da seguinte pergunta: como se configuram os planos de aula de Língua Portuguesa disponibilizados em plataformas virtuais voltadas para o professor? A depender dessa configuração e do perfil do professor que tem acesso às plataformas, a aula arquitetada, por meio do plano de aula, pode ser ou não problematizada e ressignificada. Em caso afirmativo, as plataformas são usadas como um recurso auxiliar para o professor, reclamando uma autonomia intelectual para que as ressignificações necessárias sejam feitas. Em caso negativo, as plataformas achatam a função do professor, produzindo um reducionismo das relações de sala de aula e do próprio objeto de trabalho do professor.

No caso do professor de Língua Portuguesa, o ensino e a aprendizagem de conteúdos relativos ao eixo "Prática de análise linguística" reclamam uma atenção especial. A discursividade oficial estabelece que, para se propor uma aula pautada nesse eixo, é preciso partir e chegar ao texto, mostrando como os níveis da língua, em integração, produzem sentido(s) no e pelo texto. Segundo essa discursividade, os níveis linguísticos são: fonético, fonológico, morfológico, sintático, semântico, pragmático e discursivo. Desse modo, o foco de ensino não é mais a palavra ou a frase e, sim, a análise do texto. Vejamos, a seguir, um trecho dos PCN em que essa posição está marcada:

O que deve ser ensinado não responde às imposições de organização clássica de conteúdos na gramática escolar, mas aos aspectos que precisam ser tematizados em função das necessidades apresentadas pelos alunos nas atividades de produção, leitura e escuta de textos. O modo de ensinar, por sua vez, não reproduz a clássica metodologia de definição, classificação e exercitação, mas corresponde a uma prática que parte da reflexão produzida pelos alunos mediante a utilização de uma terminologia simples e se aproxima, progressivamente, pela mediação do professor, do conhecimento gramatical produzido. Isso implica, muitas vezes, chegar a 
resultados diferentes daqueles obtidos pela gramática tradicional, cuja descrição, em muitos aspectos, não corresponde aos usos atuais da linguagem, o que coloca a necessidade de busca de apoio em outros materiais e fontes. (BRASIL, 1998, p. 29)

Frente a essa complexidade do eixo "Prática de análise linguística", essas plataformas acabam sendo muito acessadas, fazendo com que o material disponibilizado ganhe certa circulação entre os professores, por exemplo.

Neste artigo, concentrar-nos-emos em analisar e problematizar o modo como os planos de aula de Língua Portuguesa se configuram em plataformas virtuais voltadas para o professor. A partir da compreensão dessa configuração, identificaremos se os planos de aula disponibilizados estão alinhados às diretrizes oficiais do ensino de Língua Portuguesa; analisaremos como são discursivizadas as projeções metodológicas nos planos de aula em termos de proposição da futuridade da aula de Língua Portuguesa; analisaremos o modo como se apresentam os constituintes do plano de aula de Língua Portuguesa, dada a necessidade de um "efeito de unidade" para a aula.

Este artigo sustenta-se na Análise de Discurso (AD) francesa formulada por Michel Pêcheux. Com base na noção de "rede de memória", partimos do princípio de que há sentidos que se historicizam sobre o que é "ser professor" e sobre "como sê-lo". Essa historicização ganha circunscrição, por exemplo, a partir de discursividades oficiais. Não é à toa que há todo um dispositivo governamental que se dá por meio de diretrizes para os cursos de graduação, bem como para o ensino e a aprendizagem na educação básica. Sob o viés discursivo, é possível dizer que essa historicização de sentidos é fruto de forças discursivas que se marcam por meio de práticas na sociedade. Na esteira da $A D$, é possível dizer, também, que há uma divisão desigual dos sentidos que se constitui, historicamente, na sociedade.

Um exemplo de forças discursivas que podemos mencionar é a discursividade que estabiliza sentidos sobre o alto índice de "fracasso escolar" de muitos alunos nos anos iniciais (no processo de alfabetização) e nos anos finais (no processo de letramento), após as décadas de 80 e de 90, em escolas brasileiras. Essa discursividade apregoa que, a partir dessas décadas, houve uma mudança no perfil de aluno que a escola recebia. Essa mudança imprimiu forças discursivas para se transformar a natureza do ensino e da aprendizagem. É, por isso, que houve a constituição de discursividades oficiais, criando uma agenda pedagógica acerca da necessidade de se desenvolver no aluno a sua "competência discursiva".

Por consequência, essa força discursiva implicou efeitos no perfil de formação do professor de Língua Portuguesa, uma vez que ela deslocou o foco de ensino: da frase para o texto. Da parte do professor, em termos de sua formação, essa discursividade fez significar que seria preciso um currículo acadêmico que o auxiliasse na composição de seu objeto de trabalho. Assim, o currículo acadêmico, como dispositivo em que a divisão desigual de 
sentidos se acentua, precisou contemplar teorias que tomam a linguagem como instância de interação social. E mais: em termos didático-pedagógicos, fez significar que seria preciso teorias que ajudassem alçar o texto a objeto de ensino e de aprendizagem. Essas teorias tornaram-se, assim, base para a proposição de mo(vi)mentos de projeções metodológicas a serem feitos, vislumbrando a aula em sua futuridade e em seu acontecimento discursivo.

À luz discursiva, concebemos que o processo de formação teórica e didáticopedagógica pressupõe um sujeito constituído sócio-histórica e ideologicamente que possa ocupar o lugar de saber-fazer o jogo da sala de aula. Intervém, nessa formação, o processo de identificação que é constitutivo ao sujeito. Sendo assim, não é possível falar em formação idealizada, mas naquela possível, à medida que esse processo de identificação inscreve o sujeito em algum tipo de relação com o saber. A rede de memória ganha, então, contornos singulares e específicos para cada envolvido.

\section{A aula e seu jogo discursivo: do lugar das projeções metodológicas}

Nesta seção, abordamos a aula como acontecimento discursivo, a fim de expor o olhar-leitor a essa concepção. Nessa perspectiva, a aula é tomada como uma instância que compreende dois tempos: o tempo de planejamento, em que o "plano de aula" assume relevância, e o tempo de execução do planejamento, em que a contingência produz seus efeitos sobre a aula planejada. A complexidade está justamente na disjunção entre esses tempos, já que a futuridade desta é de outra ordem, que não aquela das projeções metodológicas.

A depender do modo como se concebe a relação entre esses dois tempos, a própria definição de aula ganha contornos diferentes. Se aludidos pela discursividade de espelhamento, como se fosse possível, a aula seria a mera aplicação do planejamento no mo(vi)mento da aula. Se filiados à discursividade da disjunção, a aula seria um mo(vi)mento de revezamento (contraditório) entre tais tempos. A noção de revezamento barra a perspectiva de espelhamento entre esses tempos e põe em jogo a necessidade de que é na e pela enunciação que o revezamento se constitui. A enunciação é o lócus de passagem de um tempo a outro, tendo, dada essa disjunção, a contradição como dimensão constitutiva. Assim sendo, a contradição não pode ser superada ou resolvida e nem pode ser concebida ao modo do senso comum, que a relaciona à ideia de "incoerência". A contradição é tomada como a alteração do processo, no caso trata-se do planejamento e da aula em si. Esse revezamento refere-se à passagem que a disjunção entre os referidos tempos faz trabalhar no acontecimento da aula. É entre o jogo discursivo da aula planejada e da aula acontecendo, em sua relação inextricável, que a contradição opera efeitos e constrói a experiência professoral.

A contradição é uma categoria teórico-analítica importante para a $A D$, uma vez que permite lidar com a falha constitutiva do ritual ideológico. Ela diz respeito ao fato de que o 
processo de constituição do sujeito não é pleno nem bem-sucedido; não é linear em termos de uma suposta uni(ci)dade de sentido. É que, para a $A D$, não se nasce sujeito, mas se torna sujeito, dadas às condições sócio-históricas e ideológicas de constituição. Desse modo, o sujeito é concebido em sua sobredeterminação histórica. Essa sobredeterminação é marcada por um processo de interpelação, isto é, pela passagem da condição de indivíduo à condição de sujeito. Na esteira de Althusser (1985), Pêcheux mostrou-nos que essa passagem se marca no discurso, a ponto de se delinear uma tomada de posição. Há, nessa passagem, um processo complexo de interpelação ideológica, que, segundo Pêcheux ([1979]2009, p. 277), "supõe reconhecer que não há ritual sem falhas [...]".

A contradição refere-se ao fato de que os sentidos definitórios da constituição do sujeito podem assumir outras discursividades. Os sentidos são passíveis de se alterarem na medida em que o processo de constituição se desenrola. O ritual de interpelação abre os sentidos para aquilo que Pêcheux, em 1975, concebe como "reprodução/transformação". Como implicação conceitual, a contradição não pode ser pensada como (1) oposição de duas forças e (2) oposição entre "reprodução" e "transformação". Os sentidos, em sua divisão desigual, são passíveis de assumirem outras orientações. Não é à toa que Pêcheux, em 1975, marca a relação entre "reprodução" e "transformação" por meio de "barra", colocando em evidência uma contiguidade entre eles, de modo a marcar que os sentidos sempre-já podem se tornar outros.

Os sentidos, em sua base material, que pode ser a língua, são marcados por "[...] pontos de deriva possíveis, oferecendo lugar à interpretação" (PÊCHEUX, [1983]2008, p. 53). Na elaboração de 1983, Pêcheux trabalha o conceito de real em função da relação entre estrutura e acontecimento, relacionando sintaxe e real, a fim de lidar com os furos na estrutura como lugares de emergência do acontecimento. Assim sendo, o real diz respeito àquilo que é inassimilável simbolicamente; aquilo que dispersa o efeito de uni(ci)dade. Nessa medida, "[...] todo enunciado é intrinsecamente suscetível de tornar-se outro, diferente de si mesmo, se deslocar discursivamente de seu sentido para derivar para um outro [...]" (PÊCHEUX, [1983]2008, p. 53).

Pêcheux, na elaboração de 1975, problematiza e questiona as discursividades que, imaginariamente, separam "reprodução" e "transformação", polarizando-os. Não há uma correspondência de um polo ao outro. Dessa maneira, o próprio Pêcheux (1975) concebe essa não correspondência como efeito do que, nessa época de sua elaboração, ele chamou de "'intrincação' das formações discursivas nas formações ideológicas [...]" (PÊCHEUX, [1975]2009, p. 147). Buscando produzir decorrências dessa teorização para este artigo, é possível dizer que a relação entre o tempo de planejamento e o tempo de execução do planejamento em aula é marcada por essa intrincação. Não há, como vimos defendendo, uma relação de pura equivalência entre tais tempos.

Um dos modos de se fundamentar essa não equivalência é pensar que a enunciação produzida por um sujeito faz a relação entre os tempos falhar. Ao estarem inscritos em cada tempo, o sujeito é levado a tomar posição dado o processo de interpelação específico e 
constitutivo de cada tempo. No primeiro tempo, considerando a tarefa de se planejar, as tomadas de posição são de uma ordem: a da projeção. Há um jogo discursivo produtivo e necessário que ancora o lugar das projeções imaginárias. No segundo tempo, tendo por base a tarefa de se fazer a aula em si acontecer, as tomadas de posição são de outra ordem: a da execução. Como já ressaltamos, há a incidência da contingência, que coloca os sujeitos em outro tipo de relação com certos acontecimentos que provocam ruptura naquilo que é da ordem da projeção e que, por isso, reclamam outros sentidos no exercício da aula.

Tomar partido pela enunciação para aludir à relação entre esses tempos significa por a tônica no sujeito que se deflagra no e pelo discurso. Ao enunciar, estando inserido em cada tempo, o sujeito faz movimentar as redes de memórias próprias de cada tempo. Nesses tempos, os sentidos se repetem e são (re)atualizados, fundamentando práticas próprias e específicas do tempo do planejamento e do tempo da aula. Sendo assim, a repetição de sentidos e a sua estabilização acabam por construir um certo imaginário sobre o que seria uma aula.

Como efeito do imaginário, no tempo do planejamento, a necessidade e a relevância da elaboração de plano de aula assumem lugar de destaque. Não é à toa que os discursos pedagógicos investem na importância do planejamento, destacando a função de cada constituinte do plano. Tais discursos sustentam que a elaboração de planos de aula são tentativas produtivas e necessárias de dar consistência à aula. Na perspectiva discursiva, o plano funciona como um mecanismo de antecipação importante, mas não suficiente para garantir o acontecimento da aula.

Oliveira e Chadwick (2004), filiados aos discursos pedagógicos, destacaram que o plano de aula precisa ter o seguintes constituintes: (1) "assunto", (2) "objetivo(s) específico(s)", (3) "pré-requisitos", (4) "o que deverá ser revisto na aula", (5) "considerações sobre motivação/representações poderosas/aplicações práticas", (6) "atividades a serem desenvolvidas", (7) "materiais necessários", (8) "como avaliar" e (9) "referências". Além desses elementos, é necessário definir o ano escolar e o tempo de duração da aula. $A$ depender do teórico, estes constituintes podem receber outras denominações e não seguir a mesma estruturação. É mais comum haver os constituintes (1), (2), (6), (7), (8) e (9) nos planos de aula.

A estruturação desse modelo de plano de aula, dá mostras da antecipação no planejamento. Projeta-se a futuridade da aula, estando no tempo do planejamento. Eis, nessa projeção o lugar de "intrincação". Em todos os constituintes, há a intervenção do olhar do professor para a projeção dessa futuridade. Por exemplo, no constituinte (3) "prérequisitos", o professor, tendo por base o assunto da aula, projeta os pontos que serão tomados como pré-requisito para atingir os objetivos da aula. Nesse sentido, já há ali, em jogo, uma projeção de imagem de aluno que determina aquilo que o professor toma como pré-requisito. Assim, ao propor certos pré-requisitos, o professor trabalha com uma condição a priori e, por isso, idealizada da aula. 
A partir dos possíveis pré-requisitos, o professor, já no constituinte (4) "o que deverá ser revisto na aula", propõe os pontos que deverão ser revistos. No constituinte (5) "considerações sobre motivação/representações poderosas/aplicações práticas", o professor deve construir pontos estratégicos que visem a captar, imaginariamente, a atenção dos alunos para a aula. Alguns discursos pedagógicos difundiram, com certa veemência, a perspectiva da "motivação", como se ela estivesse ao pleno controle do professor, dando garantias de que o ensino e a aprendizagem pudessem efetivar-se.

Também, nesse constituinte, é possível notar o funcionamento da "intrincação" entre tempos. Considerando o (1) "assunto", os (2) "objetivos específicos", os (3) "pré-requisitos" e (4) "o que deverá ser revisto na aula", fomenta-se o jogo de antecipação sob a égide da "motivação", buscando colocar os alunos no circuito do processo de aprendizagem. Atrelados aos outros constituintes, o professor deve propor (6) "atividades a serem desenvolvidas", estabelecendo (7) "os materiais necessários" e o modo de (8) "como avaliar". Por fim, em termos de plano de aula, é preciso mencionar as (9) "referências que ancoram a proposição da aula.

Para dizermos do foco deste artigo, os discursos pedagógicos oficiais apregoam que estes constituintes do plano precisam estar ancorados em gêneros textuais, compondo uma "sequência didática de gênero". No espaço escolar brasileiro, os discursos teóricos que propuseram a sequência didática, como uma forma de progressividade ao ensino, circulam em relação de dominância. Segundo Dolz e Schneuwly (2004, p. 97), pesquisadores filiados ao Grupo de Genebra, a sequência didática diz respeito a "um conjunto de atividades escolares organizadas, de maneira sistemática, em torno de um gênero textual oral ou escrito".

A sequência didática, na perspectiva desses teóricos, compreende duas etapas que devem estar articuladas entre si. A primeira etapa é denominada "produção inicial" e a segunda etapa é denominada "produção final". A primeira etapa é estruturada em módulos: "módulo 1", "módulo 2" até "módulo n". No Brasil, o gênero foco da sequência didática é, geralmente, trabalhado em seus aspectos constitutivos e sócio-históricos antes do trabalho com a sequência didática propriamente dita. Na "produção inicial", o aluno faz uma produção textual inicial do gênero. Nessa produção, o aluno deixa (entre)ver o modo como ele entende o gênero e os problemas de escrita a ele implicados. Em termos de planejamento, essa amostragem possibilita ao professor produzir outras intervenções, para além daquelas planejadas, buscando fomentar a identificação e a produção em si do gênero textual em estudo. Nas palavras de Dolz e Schneuwly (2004, p. 102), "a produção inicial tem um papel central como reguladora da sequência didática, tanto para os alunos quanto para o professor". Nos módulos, fomenta-se o trabalho pedagógico com os possíveis problemas linguísticos identificados na produção inicial. Na "produção final", é possível perceber os efeitos dos módulos na aprendizagem do aluno. Para Dolz e Schneuwly (2004, p. 106), a "sequência é finalizada com uma produção textual que dá ao aluno a possibilidade de pôr em prática as noções e os instrumentos elaborados separadamente nos módulos". Nessa 
etapa, a escrita, sobretudo a (re)escrita, ganha relevância, uma vez que, nesse momento, o aluno é levado a regular e a controlar seu percurso de (re)escrita.

A sequência didática, para Dolz e Schneuwly (2004), pode possibilitar que o aluno desenvolva uma certa compreensão da escrita como processo, pois, com objetivos bem delineados e com atividades sequenciais interligadas, o aluno é (re)conduzido em sua aprendizagem. Nesse caso, em termos procedimentais, as intervenções do professor no(s) texto(s) orais e/ou escritos do aluno assumem relevância na sequência didática. $E$, nessa perspectiva, a produção final figura como um mo(vi)mento importante para a reflexão do aluno.

Nas diretrizes oficiais do ensino de Língua Portuguesa, essa discursividade produziu efeitos, pois fomentou o ensino pautado em "módulos didáticos". Na discursividade oficial presente nos Parâmetros Curriculares Nacionais (PCN) de Língua Portuguesa definem-se "módulos didáticos" como:

[...] sequências de atividades e exercícios, organizados de maneira gradual para permitir que os alunos possam, progressivamente, apropriar-se das características discursivas e linguísticas dos gêneros estudados, ao produzir seus próprios textos. (BRASIL, 1998, p. 88).

Segundo a discursividade oficial, o planejamento da aula de Língua Portuguesa precisa, por conseguinte, estar alinhado à perspectiva dos módulos didáticos. Uma vez arquitetada a aula, por esse imaginário que é próprio da etapa do planejamento, o tempo de execução deste põe o professor em outra relação com o próprio planejamento, uma vez que há a contingência da aula. Considerando a especificidade da aula de Língua Portuguesa, como vimos salientando, a partir dos discursos teóricos e pedagógicos, demanda-se do professor uma formação teórica e didático-pedagógica sobre a "sequência didática de gênero". Nesse caso, uma competência de gestão entre os módulos que constituem a sequência didática, a ponto de oportunizar ao aluno uma relação significativa com o gênero textual foco da sequência didática, é necessária. A depender do gênero, a estruturação e a composição, bem como o trabalho de (re)escrita, assumem especificidades, que devem ser alçadas a objeto de reflexão pelo professor.

Nessa passagem a objeto de reflexão, as intervenções do professor no texto do aluno são importantes e necessitam de procedimentos consistentes. São procedimentos que não seguem um receituário. A depender da singularidade e da diversidade, eles ganham diferentes feições na contingência aula. Cabe ressaltar que o investimento teórico e didático-pedagógico, imaginariamente, foi significado como suficiente para que o resultado esperado fosse alcançado e que resultados não esperados fossem frutos da má execução da sequência didática. Do modo como ela foi implementada, no espaço escolar brasileiro, é como se essa metodologia de ensino não tivesse limites e, por isso, desse conta de todo o processo de ensino e de aprendizagem. 
De nossa perspectiva teórica, não é possível julgar de antemão o funcionamento da "sequência didática de gênero", como metodologia de ensino e de aprendizagem, embora a perspectiva da progressividade de atividades e de exercícios, em módulos didáticos, possa possibilitar a deteç̧ão de problemas, bem como a definição e a implementação de possíveis intervenções. Na condição de contínuo, os módulos didáticos podem permitir intervenções sistemáticas em que o aluno possa apropriar-se, progressivamente, dos saberes relativos ao gênero.

Contudo, dada a nossa discussão, o funcionamento da sequência didática pressupõe o modo como os envolvidos se identificam ou não com essa perspectiva. Essa (im)possibilidade de identificação perpassa a formação teórica e didático-pedagógica do professor. Além disso, cabe destacar que o ritual de interpelação do professor, no tempo de planejamento e no tempo de execução deste em aula, não é pleno nem bem-sucedido. Não se dá de modo idealizado como se bastasse seguir os procedimentos da "sequência didática de gênero". Não é pleno nem bem-sucedido, no sentido de que as relações não são absolutas nem exatas.

A partir da perspectiva discursiva, é possível destacar que muitos professores, ao serem interpelados por sentidos atinentes a esses discursos, produzem uma tomada de posição que acaba deflagrando uma relação prescritiva e monolítica com essas discursividades. É prescritiva e é monolítica porque muitos professores se voltam para elas somente para segui-las, sem necessariamente problematizá-las em suas possibilidades e em seus limites, permanecendo no nível da reprodução automatizada.

\section{Planos de aula: problematizações sobre as projeções metodológicas}

Nesta seção, analisamos dois planos de aula direcionados ao professor de Língua Portuguesa. Trata-se de planos disponibilizados em plataformas virtuais e de acesso gratuito. O primeiro plano de aula intitulado "Jogo da memória de pronomes", está disponibilizado no portal UOL, no link "Educação". O segundo plano de aula, denominado "Língua Portuguesa Diferenciando correspondências", está disponível no "Portal do professor", no site do Ministério da Educação (MEC) ${ }^{4}$. Para a seleção dos planos, foi solicitado a Ronis A. Gouveia que elegesse um de cada plataforma, sob a orientação de serem planos de aula de Língua Portuguesa. Dado nosso interesse analítico, que se prende, particularmente, às projeções metodológicas que esses planos de aula apresentam, não houve necessidade, por exemplo, de que os planos abordassem o mesmo assunto ou da adoção de outros critérios.

Iniciamos a análise apresentando a configuração de cada plano, buscando mostrar os seus constituintes. Como ressaltamos na seção anterior, não há uma configuração

\footnotetext{
${ }^{4}$ Esses planos de aula foram acessados em março de 2018.
} 
consensual dos planos de aula, o que não necessariamente implica um problema em si. Interessa-nos, acima de tudo, compreender como o efeito de unidade do plano se constitui. $E$, em seguida, deter-nos-emos nas projeções metodológicas, que, no primeiro plano de aula, estão mencionadas na seção "Estratégias" e, no segundo plano, na seção "Atividades desenvolvidas pelo professor".

O primeiro plano de aula é constituído das seguintes seções: (1) "Objetivos", (2) "Ponto de partida", (3) "Estratégias" e (4) "Comentários". A seção "Objetivos" apresenta dois objetivos, a saber: "1) Reconhecer a função dos pronomes para a construção de sentidos nas diferentes situações comunicativas. 2) Reconhecer e classificar os pronomes". 0 primeiro objetivo, dada sua formulação, autoriza ler que o ensino do tópico gramatical "Pronomes" deve orientar-se pela função dos pronomes, particularmente a função que podem assumir nas "situações comunicativas". Assim, a rede de memória sobre o ensino de Língua Portuguesa, particularmente a discursividade que ressignificou o ensino de gramática normativa a partir dos gêneros textuais, ganhou uma (re)atualização. Estamos concebendo essa (re)atualização, no sentido de que, na condição de "objetivos", a perspectiva funcional da língua é discursivizada. Olha-se para o modo como os pronomes participam da construção de sentidos, tendo por base o uso da língua. O adjunto adverbial de lugar "nas diferentes situações comunicativas" acaba por generalizar o foco de onde a construção de sentido será pensada. Nesse caso, não se faz recorte específico. Esse recorte terá, então, que ser feito pelo professor.

O segundo objetivo, do modo como está textualizado, prioriza a forma, pois assume como foco o reconhecimento e a classificação dos pronomes. Trata-se de uma perspectiva morfológica sobre os pronomes, tendo em vista esse constituinte do plano de aula. - a seção dos "objetivos". Também, neste ponto, a rede de memória sobre o ensino de Língua Portuguesa se (re)atualiza. Desta vez, em relação à identificação da forma e à sua classificação. Há discursividades que defendem a não formalização dos conceitos e, por decorrência, a classificação no ensino fundamental e outras que defendem a necessidade de se formalizar a metalinguagem desde o ensino fundamental. Eis, no espaço escolar brasileiro, a divisão desigual dos sentidos em operação, na qual cada ponto de vista ganha uma circunscrição histórica diferente.

Estamos ressaltando a perspectiva de que o modo de instrução dos "objetivos" deixa entrever a orientação teórica da aula significada na formulação dos objetivos em questão, a partir dos efeitos das redes de memória que constituem o ensino de Língua Portuguesa. Se nos orientarmos pela historicidade desse ensino, perceberemos as diferentes discursividades em operação, marcando pontos específicos "do que ensinar" e "do modo como ensinar". Seja orientando pela forma, seja pela função, sobretudo pela integração entre uma e outra, há condições históricas que produzem evidências para a sustentação ou para a problematização de uma perspectiva ou de outra.

Após a ocorrência dos objetivos, a seção "Ponto de partida" traz sugestões das cartas que constituem o "jogo da memória". As primeiras são as cartas de classificação, que 
recebem a terminologia gramatical dos tipos de pronomes: "pronome pessoal do caso reto", "pronome pessoal do caso oblíquo", "pronome demonstrativo", "pronome de tratamento", "pronome possessivo", "pronome indefinido", "pronome interrogativo" e "pronome relativo". As segundas são as cartas com exemplos. Trata-se de oito recortes de músicas de variados cantores brasileiros.

Consideremos, a seguir, os recortes do gênero "música", que compõem as cartas com exemplos; os destaques, em negrito, constam do original: (1) "Eu penso em você/Desde o amanhecer/Até quando eu me deito." (Tribalistas); (2) "Já sei namorar/Já sei chutar a bola/Agora só me falta ganhar." (Tribalistas); (3) "Cada paralelepípedo/Da velha cidade/Essa noite vai/Se arrepiar." (Chico Buarque); (4) "Você/É algo assim/É tudo pra mim/É como eu sonhava, baby." (Tim Maia); (5) "Meu filho vai ter/nome de santo/Quero o nome mais bonito."; (6) "É o que foi/Prometido,/Ninguém prometeu." (Legião Urbana); (7) "Quem me chamou/Quem vai querer/Voltar pro ninho/ Redescobrir seu lugar." (Guilherme Arantes); (8) "Eu vou contar pra todos a história de um rapaz/Que tinha a muito tempo a fama de ser mal." (Roberto Carlos).

$\mathrm{Na}$ sequência do plano, após a apresentação dos recortes, é apresentada uma observação ao professor, qual seja: "Coloquei apenas um exemplo de cada classificação e escolhi trechos de músicas, mas o interessante é apresentar pelo menos dois exemplos de cada tipo de pronome e escolher trechos de textos trabalhados em aula". Por mais que se ressalte que foram escolhidos trechos de músicas, para essa possível aula sobre "pronomes", não se apresenta uma justificativa do porquê da seleção desse gênero. Alguns questionamentos se (im)põem: (1) a escolha do gênero "música" se deu pelo fato de ser um possível gênero com o qual os alunos se identificariam?; (2) a escolha do gênero foi feita, porque, imaginariamente, ele pode possibilitar um efeito lúdico para a aula, ao se trabalhar os "pronomes"?; (3) a escolha está assentada na questão de que esse gênero se mostra produtivo para se trabalhar o modo como os pronomes participam da construção do sentido das músicas?; (4) a escolha desse gênero está em função da possibilidade de memorização que ele oportuniza?

Do modo como o plano está estruturado, sem a menção explícita do público-alvo, não é possível propormos uma resposta cabível à primeira pergunta. É possível pensar que o gênero possa ser um texto com o qual os alunos se identificariam. Contudo, as músicas selecionadas para a aula podem não ser. O tipo de música acaba projetando o perfil do aluno para o qual a aula é arquitetada. Uma projeção de resposta à segunda pergunta pode se orientar pelo campo da afirmação, uma vez que está em operação, nessa aula, uma discursividade de que as aulas precisam ser lúdicas, sobretudo se for aulas de "gramática normativa". No espaço escolar, propalou-se essa discursividade, concedendo à ludicidade prevalência. Fragmenta-se e superficializa-se, a depender dos envolvidos, o conteúdo em prol de uma suposta "aula prazerosa".

Já uma projeção de resposta à terceira pergunta, assenta-se no campo da negação. $A$ operacionalização do gênero música, na aula arquitetada, não deixa entrever o trabalho com 
os processos de construção de sentidos no texto. Não se aborda, por exemplo, os efeitos de sentido que os pronomes produzem na música em seu resultado pontual e global. O máximo que o jogo permite é o exercício de classificação do tipo de pronome. Para o segundo objetivo da aula, o "jogo da memória de pronomes" pode cumprir bem a função. Contudo, o mesmo não se dá em relação ao primeiro objetivo. Uma projeção de resposta à quarta pergunta assenta-se no campo da afirmação, pois há discursividades que apregoam que o gênero textual música favorece o trabalho com a memória.

Ainda com base na observação direcionada ao professor, sobretudo na oração encabeçada pela conjunção adversativa "mas" ("[...] mas o interessante é apresentar pelo menos dois exemplos de cada tipo de pronome [...]"), é possível perceber que a escolha está em função da necessidade de se ilustrar os diferentes tipos de pronomes. A informação que se segue, encabeçada pela conjunção aditiva " $e$ " ("[...] e escolher trechos de textos trabalhados em aula [...]"), reforça o argumento de que a escolha do gênero "música" é feito para a mera ilustração dos tipos de pronomes. Por mais que se mencione, no primeiro objetivo, a questão da construção de sentido no e pelo gênero, na proposição da aula como um todo, essa questão esvai-se.

A recomendação de que seria possível substituir os trechos da música por outros "textos" trabalhados em aula permite-nos aventar a hipótese de que o gênero escolhido não cumpre uma função específica na aula em questão. A possibilidade de substituição mostra que a tônica ainda é a diferenciação dos tipos de pronomes. Essa consideração não implica a defesa da perspectiva de que não se deve ensinar gramática normativa em aulas de Língua Portuguesa. Estamos chamando a atenção para a complexidade do que é tomar o texto como ponto de partida e de chegada. E que, inclusive, a ancoragem no e pelo texto reclama critérios consistentes de seleção deste para o ensino de Língua Portuguesa. Esperava-se, por exemplo, que fosse destacado que a escolha do gênero está assentada no modo como o gênero "música" ancora a construção de sentido, tendo os "pronomes" como elementos constituintes dessa construção. Considerando, a aula arquitetada seria trabalhar os efeitos de sentido que os pronomes produzem em cada música.

Na seção "Estratégias", são apresentados dois blocos de informação para o professor. No primeiro, é dado o comando de que será necessária uma revisão sobre os tipos de pronomes antes da realização do jogo. Em forma de inserção parentética, destaca-se a seguinte informação: "[...] na construção de sentidos em diversas situações comunicativas [...]". Na sequência das recomendações, salienta-se a necessidade de organização da turma em pequenos grupos após a revisão. Uma vez organizados os grupos, orienta-se que sejam distribuídos os envelopes em que há as cartas do jogo. É feita a recomendação de que os próprios alunos podem produzir o material do jogo: cartas de classificação, cartas com exemplos e envelopes. Na última recomendação constante do primeiro bloco de estratégias, é destacado que os alunos podem, também, construir as regras do jogo e "uma síntese sobre o estudo realizado". 
Chamamos a atenção, nesse bloco de "estratégias", para a inconsistência da recomendação da revisão sobre a função dos pronomes na "construção de sentidos em diversas situações comunicativas", sem assinalar os parâmetros necessários para tal fim. Como se trata da seção "Estratégias", seria necessário expor, em linhas gerais, modos de se operacionalizar essa construção de sentidos, funcionando nos recortes de música selecionados. Esses modos referem-se às projeções metodológicas possíveis para se arquitetar a aula no tempo do planejamento. Um questionamento se (im)põe neste ponto: a que se prende o apagamento dessas projeções metodológicas nessa aula? Na condição de analistas de discurso, podemos construir alguns espaços de interpretação, propondo considerações ao questionamento. Da perspectiva discursiva, não é possível fecharmos os sentidos, o que significa dizer que não há uma resposta pronta, acabada e definitiva ao questionamento.

Um primeiro espaço de interpretação considera que esse apagamento está em função do fato de a aula arquitetada ser orientada pela perspectiva gramatical da língua, de modo que a identificação da forma é que passa a ser relevante. Um segundo espaço de interpretação propõe que tal apagamento é referente ao movimento de se tangenciar a perspectiva funcional da língua. Essa perspectiva assinala que a integração entre forma e função é relevante. Contudo, esse tangenciamento pode ser lido como efeito da complexidade do que é produzir essa integração. Como as diretrizes oficiais do ensino de Língua Portuguesa discursivizam essa integração, acaba sendo preciso mobilizá-la em aulas de Língua Portuguesa.

No segundo bloco de informações, apresentam-se algumas instruções para a operacionalização do jogo em si. Uma inserção parentética é produzida, após a seguinte inscrição "2) Instruções para o jogo", salientando que as instruções propostas são sugestões. Consideremos, a seguir, as instruções recomendadas:

[...] colocar todas as cartas com exemplos viradas para baixo e as de classificação no canto da mesa, para serem compradas. Definir quem iniciará o jogo. Em seguida, o aluno deve comprar uma carta com a classificação do pronome e virar uma carta com exemplo. Se o exemplo corresponder à carta de classificação comprada, ele marca ponto e/ou joga novamente. Essas regras podem ser criadas pelos próprios alunos. (SBROGIO, 2018, s/p.)

A dinâmica do jogo é muito próxima ao "jogo de memória" tradicional em que o participante faz uma comparação entre cartas, de maneira a identificar a igualdade entre elas. A disposição das cartas e a memória do participante são pontos decisivos para a vitória no jogo. No "jogo da memória dos pronomes", como já anuncia o próprio título do plano de aula, a diferença consiste no fato de que o participante necessita saber o conceito e a classificação dos diferentes pronomes para proceder à compra das cartas. Esse saber gramatical é decisivo, no jogo para que a compra das cartas com os exemplos seja feita 
corretamente. Por se tratar de um jogo, a aula arquitetada é baseada na competição entre os alunos. Desse modo, o fundamento para se construir as condições de identificação dos alunos com o conteúdo em si, ainda que imaginárias, está assentado na discursividade lúdica.

Por fim, no plano de aula em análise aparece a última seção "comentários". Dois comentários são apresentados. O primeiro refere-se à informação de que a aula proposta no plano deve ser ministrada após uma aula em que houvesse um "estudo sistemático sobre pronomes". O segundo concerne à informação de que a construção do próprio jogo pode ser feita durante o estudo sistemático sobre os pronomes, bem como os próprios alunos podem proceder à seleção dos exemplos e ao estabelecimento do modo como o jogo se dará.

Chama-nos a atenção, nesses comentários, o modo pouco circunstanciado e fundamentado com que as informações são postas. No primeiro comentário, o sintagma "estudo sistematizado" reclama alguns questionamentos. O que seria um "estudo sistematizado" sobre os pronomes? Como levar a bom termo uma aula em que esse estudo sistematizado se dê? Não podemos nos esquecer, à luz dos dois objetivos constantes do plano, de que esse "estudo sistematizado" deve permear a forma e a função dos pronomes. Contudo, nesse comentário, não é discursivizado como deve ser a implementação do "estudo sistematizado".

Em relação ao segundo comentário, dizer que a construção do jogo e o "estudo sistematizado" podem se dar em concomitância é inespecífico. Ainda que na condição de comentário alguns horizontes poderiam ser traçados para o professor. Com esse comentário, a nossa hipótese de que essa aula arquitetada é constituída pelos efeitos da discursividade lúdica se acentua. Recomenda-se que os alunos, além de selecionarem outras ocorrências de pronomes para compor as "cartas de exemplo", poderiam eleger um outro tipo de jogo, de maneira a contemplar o conteúdo foco da aula. O aspecto central dessa aula é o jogo em si, pois tanto a proposição feita, que é "jogo da memória de pronomes", quanto a opção sugerida que é "outra forma de jogo", estão circunscritas a uma suposta temática lúdica.

A crítica tecida a esse plano de aula não se refere somente ao modo como o gênero "música" é mobilizado, mas também ao fato de que não são expostos os modos para se levar a bom termo uma aula sobre pronomes, tendo por base o gênero textual "música". Não é discursivizado de que modo integrar "forma" e "função" referente aos pronomes a partir deste gênero. Essa crítica refere-se a uma etapa relevante do planejamento da aula em Língua Portuguesa, a saber: a seleção dos gêneros textuais a serem trabalhados na aula e as suas relações com os objetivos desta. É esperado que, na metodologia, por esta ser um constituinte importante do plano de aula, seja explicitada a descrição do modo como o gênero selecionado pode oportunizar o cumprimento dos objetivos. No caso em questão, não há essa explicitação. Com essa ausência, a formulação faz significar que a seleção desse gênero está em função tão-somente da ludicidade. 
O segundo plano de aula, objeto de análise, é estruturado a partir das seguintes seções: (1) "Objetivos", (2) "Pré-requisitos dos alunos", (3) "Recursos /materiais de apoio", (4) "Glossário", (5) "Questões problematizadoras", (6) "Leis, princípios, teorias, axiomas, fundamentos, regras...", (7) "Para refletir com os alunos", (8) "Atividades desenvolvidas pelo professor", (9) "Tarefa dos alunos", (10) "Para saber mais", (11) "Avaliação" e (12) "Exercícios de fixação". No cabeçalho do plano de aula, aparecem informações que identificam a natureza da aula planejada. São especificadas as seguintes informações: (1) "Nível de ensino", (2) "Ano/semestre", (3) "Componente curricular", (4) "Tema", (5) "Duração da aula" e (6) "Modalidade de Ensino". Cabe informar que o plano de aula é intitulado "Diferenciando correspondências".

Na seção "Objetivos", são apresentados cinco objetivos para essa aula planejada. Os dois primeiros são oriundos da "Matriz de referência de Língua Portuguesa - PAEBES: Ensino Fundamental e Médio". Os outros três referem-se à área da "Tecnologia"; por meio de uma consulta na internet, percebemos que esses objetivos estão, textualmente, muito próximos àqueles que aparecem no referencial curricular do estado de São Paulo (2009). Nesse referencial, esses objetivos, denominados de habilidades, relacionam-se ao trabalho pedagógico de compreensão de informações representadas de diferentes formas. Vejamos abaixo, os cinco objetivos:

a) D12 - F2 - PORT - Identificar a finalidade de textos de diferentes gêneros;

b) D13 - F2 - PORT - Identificar as marcas lingüísticas que evidenciam o locutor e o interloutor de um texto;

c) D1.1 - F2 - TEC - Identificar, reconhecer, indicar, apontar, dentre diversos objetos aquele que corresponde a um conceito ou a uma descrição usando sites de busca;

d) D1.3 - F2 - TEC - Identificar uma descrição que corresponda a um conceito ou às características típicas de objetos, da fala, de diferentes tipos de texto, utilizando como auxílio vídeos e celulares;

e) D1.6 - F2 - TEC - Discriminar, estabelecer diferenciações entre objetos, situações e fenômenos com diferentes níveis de semelhança, publicando informações em redes sociais. (BRASIL, 2018, p. 1)

Esses objetivos estão inscritos na discursividade de que a aprendizagem é passível de ser mensurada por meio de competências e de habilidades. No espaço escolar brasileiro, dados os efeitos dos documentos oficiais norteadores da educação básica, o processo de ensino e de aprendizagem ganhou uma circunscrição cognitiva. Passou-se a vincular os conteúdos a serem trabalhados à questão de competências e de habilidades. Se consultarmos as "Diretrizes para a formação de professores da Educação Básica (2001)", notaremos, em perspectiva, a dimensão do processo de ensino e de aprendizagem a partir de competências. Nesses discursos, as "competências são as modalidades estruturais da inteligência, ou melhor, ações e operações que utilizamos para estabelecer relações com e entre objetos, situações, fenômenos e pessoas que desejamos conhecer" (BRASIL, 2001, p. 7). Assim, as habilidades seriam um "saber fazer" gerado pelas competências. 
A partir de tais objetivos, torna-se compreensível que esse plano sustenta-se na perspectiva de ensino de Língua Portuguesa por meio de gêneros textuais e dos descritores constantes das avaliações sistêmicas. A formulação dos objetivos coloca os gêneros textuais no centro dos processos de ensino e de aprendizagem, pensando-os a partir do ciberespaço, uma vez que os descritores circunscrevem-se às áreas de Língua Portuguesa e de tecnologias de informação e de comunicação.

$\mathrm{Na}$ seção "Pré-requisitos dos alunos", são assumidas como necessárias para o acontecimento da aula as seguintes habilidades: "saber enviar e receber e-mail; ter noção de pesquisa em sites (sic) de busca; ter noção de utilização de redes sociais". Trata-se de habilidades referentes ao uso de tecnologias de informação e de comunicação. Como o plano de aula toma por base os gêneros textuais que circulam no ciberespaço, o domínio dessas habilidades é necessário. A aula planejada tematiza as diferentes correspondências, dando ênfase ao hipertexto.

$\mathrm{Na}$ seção "Recursos/materiais de apoio", são listados os materiais que são necessários à execução do plano. Desde o DVD do filme "central do Brasil" até aparelhos eletrônicos como: "aparelho de DVD, televisão, laptop educacional, telefone móvel". Citamse, também, "caneta hidrográfica" e "cartolina" como recursos/materiais de apoio.

Na seção "Glossário", são definidos os seguintes termos: "comunicação", "Gêneros textuais", "Mídia digital" e "scrap". Trata-se de conceitos mobilizados da plataforma colaborativa "Wikipédia". Dada a possibilidade de qualquer pessoa alterar as informações da plataforma, o site Wikipédia não é recomendável para este fim. Os dois primeiros termos são ligados à área de Língua Portuguesa; os dois últimos, à área da informática.

Vejamos o conceito de "gêneros textuais" apresentado no plano, para mostrarmos que há, em sua formulação, uma simplificação que excede à didatização específica do espaço escolar: "Gêneros textuais: são tipos específicos de textos de qualquer natureza, literários ou não-literários". Explicar os gêneros textuais mobilizando o sintagma tipos específicos de texto faz significar uma sobreposição entre os conceitos de "gênero textual" e "tipo textual", que diferentes discursividades da Linguística rebatem contundentemente. Da parte do professor, essa sobreposição pode significar uma solução de continuidade de sua prática docente, uma vez que ele pode compreender, então, que se trata apenas de uma alteração terminológica e que sua prática já contempla desde sempre-já certo trabalho com os gêneros textuais, já que os textos circulam no espaço escolar e, em particular, nas aulas de Língua Portuguesa.

Em relação a essa questão, certas teorizações da Linguística podem auxiliar o professor na fundamentação de que os gêneros textuais, dada a funcionalidade nos diferentes espações sociais, são passíveis de "transmutarem-se". O conceito de "transmutação" advém das proposições teóricas de Bakhtin (2000). A transformação ocorre, quando "os gêneros secundários absorvem e transmutam os gêneros primários (simples) de todas as espécies, que se constituíram em circunstâncias de uma comunicação verbal 
espontânea" (BAKHTIN, 2000, p. 281). Nesse plano de aula, pela relação entre as áreas da Língua Portuguesa e da informática, a operacionalização desse conceito pode mostrar-se importante devido ao suporte oportunizado pelo ciberespaço, como o gênero textual "carta pessoal" que pode ser concebido como transmutado para o gênero textual "e-mail". São conhecimentos teóricos que o professor, ao conhecer e compreender, pode mobilizar para subsidiar a aula e, assim, não permanecer no campo meramente informativo, mas atingir também um caráter formativo.

Outro problema deste plano de aula em relação às discursividades oficiais encontrase na simplificação do conceito de "comunicação", que pode inviabilizar a abordagem do aspecto dialógico da linguagem. Enquanto os documentos oficiais sustentam-se na perspectiva interacionista da linguagem, o conceito presente no plano sustenta-se na teoria da informação, o que produz contradição entre o plano de aula e os documentos oficiais, já que a perspectiva interacionista emerge da crítica à teoria da informação/comunicação. Assim, o "glossário" do plano de aula, ao conceituar "comunicação" como "intercâmbio de informação entre sujeitos ou objetos", orienta-se por outros caminhos que não aqueles preconizados pelos documentos oficiais e que as discursividades que os constituem tomam como "ultrapassados", pois desconsideram a complexidade da linguagem humana, concebendo a linguagem como "um instrumento de comunicação".

Já na seção "Questões problematizadoras", demanda-se que o aluno produza um circunstanciamento, mostrando qual a situação "mais adequada", na opinião dele, para se enviar: "Uma carta?", "Um convite", "Um bilhete" e "Um e-mail”. Abaixo de cada menção ao gênero textual, aparecem ilustrações deles. Vejamos o comando da questão: "Imagine que alguém que você gosta muito está distante e você gostaria de se comunicar com ela. O que você faria? Qual seria a ocasião mais adequada para enviar?". Busca-se, assim, levar o aluno a pensar no contexto de interação e os gêneros textuais que medeiam essa interação.

Na seção "Leis, princípios, Teorias, Teoremas, Axiomas, Fundamentos, Regras...", apresenta-se uma incursão teórica em torno da perspectiva dos "Gêneros Textuais", a partir daquilo que Marcuschi (2002) propõe no texto "Gêneros Textuais: definição e funcionalidade". Essa incursão é encabeçada pela definição de "gênero textual" e, em seguida, passa-se a considerar os efeitos das tecnologias de informação e de comunicação na constituição dos "gêneros textuais". A tônica da seção recai sobre as adaptações pelas quais os gêneros passam, dada a dinâmica da sociedade. Para tanto, faz-se menção às características e às funcionalidades dos gêneros textuais "carta", "bilhete", "convite" e "email", mostrando que entre esses gêneros há/haveria adaptações impostas pelo ciberespaço.

Em um plano de aula, as teorizações cumprem a função de dar ciência, ao professor, da base conceitual da aula planejada, para que o professor possa compreender o processo de didatização ali implicado. Como se trata de um plano pronto para o professor executá-lo, essa seção coloca o professor a par da teoria que fundamenta a aula. Cabe-nos ainda uma colocação: por ser um plano disponibilizado em plataforma oficial direcionada ao professor 
de Língua Portuguesa, estanha-nos o fato de a sua base teórica contrapor-se à base dos documentos oficiais. De nossa perspectiva teórica, trata-se da dispersão dos sentidos e dos sujeitos, uma vez que a unidade é um efeito da formulação. O efeito de unidade, nesse caso, para o professor pode vir pelo imaginário de que não haveria como fazer uma aula diferente. Algo parecido com o que, muitas vezes, acontece nos estágios supervisionados, em que o professor supervisor solicita ao professor em formação que planeje uma aula. E, então, quando o professor em formação ministra a aula planejada como prática de microensino, o professor supervisor observa uma aula tradicionalíssima e, daí questiona: e tudo que discutimos nas aulas?

Na seção "para refletir com os alunos", é apresentado um comentário em torno do fato de que, antes do advento dos recursos tecnológicos, a comunicação entre as pessoas era produzida por gêneros textuais como: "carta", "bilhete" e "convite". Após esse advento, a comunicação passou a ser mediada pelos recursos tecnológicos, como é o caso do computador. O envio de "bilhetes" e de "convites" passou a ser afetado também, pois se envia "scraps". No comentário, é ressaltada a agilidade que as tecnologias imprimem à comunicação entre as pessoas. Esse comentário, portanto, está pautado em discursividades que atribuem sentidos positivos às tecnologias de informação e comunicação.

Ainda nessa seção são apresentadas duas questões para reflexão em sala de aula, a saber: "Porque (sic) o contato face a face está cada vez mais raro? A tecnologia está aproximando ou distanciado mais as pessoas?" Essas perguntas buscam levar os alunos a pensar no impacto que as tecnologias de informação e de comunicação imprimem à comunicação humana. No espaço da aula, essas perguntas podem criar um mo(vi)mento de diálogo entre professor e aluno(s) em torno da temática de as interações humanas mudaram, de modo que os alunos possam perceber os sentidos em disputa sobre como as tecnologias podem e devem ser significadas.

Ademais, o modo como as perguntas são formuladas direcionam sentidos negativos aos efeitos das tecnologias de informação e de comunicação. A primeira pergunta faz trabalhar o pressuposto de que essas tecnologias substituíram o contato direto entre as pessoas. Essa substituição é significada como problemática por discursividades em circulação social e que produzem a seguinte associação: "+ contato face a face + mais aproximação entre as pessoas + vivência saudável e produtiva". A segunda pergunta, ao dar como possibilidade a relação binária entre "aproximar" e "distanciar", no gerúndio, articulada à relação de adverbialização encabeçada pelo "mais", tematiza a tecnologia como desencadeadora de um movimento de polarização. O comentário que antecede as duas perguntas: "se pararmos para refletir, até um 'bom dia' ao vizinho, às vezes, é feito através da internet", colabora para a produção dos efeitos negativos das tecnologias. Põe-se em evidência a mediação da internet como prejudicial às relações sociais.

Essas considerações sobre a leitura-interpretação das perguntas mostram que a formulação significa, uma vez que o modo de textualizar o dizer acaba por engendrar relações com o pré-construído e com o interdiscurso. Em termos discursivos, as perguntas 
instauram sentidos já postos, a partir da materialidade do enunciado das perguntas, que se vincula à constituição e à circulação de outros sentidos. Os sentidos se constituem em uma historicidade. No caso, trata-se de pensar nos sentidos que, socialmente, já se produziu e produz sobre o uso das tecnologias de informação e de comunicação.

Esse plano mantém relação com os sentidos que se constituem e que circulam na sociedade sobre o uso indiscriminado das tecnologias de informação e de comunicação. Assim, o plano, em seus "objetivos", evoca, (re)atualiza sentidos que essas discursividades significam como críticos. O pré-construído produz efeitos nas redes de memória. Nesse caso, o pré-construído concerne aos sentidos sobre o efeito das tecnologias nas interações humanas. Desse modo, a estruturação das perguntas, na proposição de uma aula, mostra-se relevante. Mas é necessário expor o aluno às diferentes discursividades em circulação e à não-transparência dos sentidos, uma vez que os sentidos respondem às relações sóciohistóricas e ideológicas que constituem a sociedade e suas instituições.

$\mathrm{Na}$ seção "Atividades desenvolvidas pelo professor", são circunstanciados os métodos que subsidiam as três aulas. Trata-se das projeções metodológicas para cada aula de Língua Portuguesa. Essas projeções dizem respeito ao tempo de planejamento, sob o imaginário que lhe é próprio. Sob o mecanismo imaginário da antecipação as aulas ganham (im)possibilidades metodológicas. Esse imaginário torna-se fundamental, pois é sob a sua égide que o efeito de unidade da aula é produzido. Contudo, no tempo de execução do planejamento, há um efeito de dispersão na condição de acontecimento.

A primeira aula descrita é iniciada pela consideração de que o professor poderá levar os alunos a refletirem sobre as correspondências. Trata-se de introduzir o assunto da aula por meio de reflexão. Nessa reflexão, está pressuposta a interação entre professor e aluno(s), de modo que este(s) seja(m) levado(s) a assumir(em) a palavra. Em termos de projeção metodológica, passa-se a sugerir ao professor algumas ações pedagógicas para a realização da aula. Por meio do vocativo "professor", e com os verbos no imperativo afirmativo, busca-se criar uma identificação do professor com as ações sugeridas. As projeções metodológicas são estruturadas de modo a destacar que o professor explicite o objetivo da aula para os alunos, inclusive que aborde o que será estudado nesta primeira aula.

Por meio de discurso direto, faz-se uma proposição de enunciado para o professor: "sempre que escrevemos para alguém que está distante de nós estamos nos correspondendo. Há vários tipos de correspondência, mas nessa aula será trabalhado apenas quatro deles: carta, bilhete, convite e e-mail". Após essa proposição, recomenda-se que seja explorada a finalidade diferente de cada gênero textual em estudo. Em seguida, recomenda-se, também, que os alunos sejam levados a fazer pesquisas, em grupos, por meio da navegação na internet. No plano, são propostos os seguintes sites: Google (www.google.com.br), bing (www.bing.com) e altavista (www.altavista.com.br) e Orkut (www.orkut.com). Essa navegação dar-se-ia por meio de "laptop educacional" ou de 
"telefones móveis" dos alunos. O foco dessa navegação seria buscar as características e as finalidades dos gêneros.

O plano de aula segue com a recomendação de que, depois dessa navegação, promova-se um debate entre os alunos e um exercício de formalização: a elaboração de um conceito para cada gênero. E, dada a natureza da aula planejada, essa formalização deverá ter como suporte a rede social orkut. Trata-se da interação entre professor e aluno(s) por meio de fórum virtual. Esse fórum precisa ser criado primeiro pelo professor e disponibilizado ao(s) aluno(s). Essa proposição de interação substitui a tecnologia de papel pela tecnologia de informação e de comunicação. Na atualidade, outras redes sociais assumiram o lugar do orkut, como o Facebook e o Whatsapp.

As projeções metodológicas seguem com a recomendação de que o professor poderá circunstanciar certas informações pertencentes à informática: “[...] colocar o assunto pesquisado entre aspas, optar por uma busca avançada, onde podemos estabelecer o formato de arquivo que queremos, o idioma etc." A partir dessas informações, fica pressuposto que, antes da participação no fórum, os alunos deverão fazer consultas na internet. Nesse sentido, o ciberespaço abre novos horizontes para a sala de aula, como o aluno compor e produzir o recorte de informações.

O protagonismo do aluno, diante desse recorte, é concebido, aos olhos de teóricos da área das tecnologias de informação e de comunicação, como possibilidade de o aluno exercer uma autonomia. É que o próprio aluno acessaria e teria contato com as diferentes informações. Do ponto de vista das referidas tecnologias, há formas rápidas e consistentes para se buscar informações na internet. Contudo, uma das críticas feitas a essa suposta autonomia refere-se à falta de critério da parte do aluno para julgar a pertinência e a consistência da informação selecionada. Sendo assim, o professor assume lugar relevante, no sentido de direcionar e de orientar o aluno nesse processo de seleção. Na sequência, o plano recomenda o diálogo entre professor e aluno(s) em torno dos conceitos por ele(s) elaborado(s). Trata-se do momento de socializar as informações coletadas e articuladas pelo(s) aluno(s). É sugerido que, por meio de cartaz, os alunos, em grupo, escrevam as características e as finalidades dos gêneros textuais em estudo. Com esse cartaz, será possível expor as ideias e deixá-las registradas para posterior consulta.

Na aula seguinte, é recomendado que o professor, por meio de uma roda de conversa, retome partes da aula anterior. Essa projeção busca dar um efeito de unidade/continuidade temática para a aula que se inicia. Nesse início, destaca-se que o cartaz produzido na aula anterior pode ser retomado. Novamente, o tópico "características e finalidades" dos quatro gêneros textuais é enfocado. Recomenda-se que professor exiba cenas do filme "Central do Brasil", buscando, em seguida, abordar a questão da escrita do gênero "cartas" para pessoas analfabetas. A proposta é que os alunos elaborem uma análise acerca das cenas do filme em questão. Em seguida, o professor deve demandar uma atividade escrita dos alunos, cujo tema da atividade é "a importância do gênero carta como meio de comunicação entre pessoas". 
Nesse ponto da aula planejada, a recomendação é de que se destaque que, no filme, a carta pessoal serviu de base para a narração de acontecimentos, sentimentos e emoções às pessoas distantes daquela que solicitava a escrita da carta. E, nesse processo de escrita, 0 filme evidencia o modo como as pessoas ditavam a mensagem e o modo como a pessoa escrevia o texto da mensagem. A projeção metodológica, para esse momento, é que o professor explore as diferenças entre o texto oral e o texto escrito, buscando relacionar o registro informal e formal, respectivamente, desses textos. No filme, essa relação pode ser mostrada a partir da análise das falas das personagens e do modo como a protagonista escreve.

Ainda no âmbito dessa projeção metodológica, recomenda-se que o professor tematize a questão de que o uso da linguagem formal ou informal está relacionada ao grau de familiaridade que se estabelece com o destinatário. Destaca-se a necessidade de explicar para os alunos que possuímos um modo próprio para falar e para escrever no processo de comunicação. É destacado, ainda, que esse processo de comunicação é regulado pela natureza do remetente. Faz-se menção ao caso de nos endereçarmos ao prefeito para apresentar uma demanda. Por ser uma situação formal, deve-se utilizar o registro formal.

Por fim, nessa aula planejada, a projeção metodológica produzida visa a que o(s) aluno(s) experiencie(m) dois tipos de interação. A primeira experiência é o envio de uma mensagem SMS, por meio de telefone móvel para um colega de turma, valendo-se de registro informal. A segunda experiência refere-se ao envio de um e-mail para a direção da escola, com cópia para o professor. Esse e-mail teria de ser produzido no registro formal da Língua Portuguesa.

$\mathrm{Na}$ terceira e última aula planejada, recomenda-se que esta seja iniciada com a retomada dos e-mails, de maneira que o professor faça um trabalho pedagógico sobre os erros e acertos encontrados neles. Sugere-se elencar os erros e os acertos que os alunos tiveram ao redigir, em registro formal, os e-mails. Na sequência, em termos de projeção metodológica, é proposta uma atividade por meio do twitter. Os alunos teriam de redigir um convite para os seus seguidores, tendo em vista o que seria um convite. Na sequência, uma atividade de correção, na qual os alunos devem ler os convites elaborados e tentar identificar os erros e os acertos do uso da língua escrita.

Ainda nessa terceira aula, ressalta-se a necessidade de que o professor explique que "os bilhetes escritos à mão estão sendo substituídos pelos scraps". É proposta a atividade de que, em dupla, os alunos troquem bilhetes (scrap), valendo-se do Facebook. A dinâmica da atividade é que um membro da dupla produza o bilhete, em registro informal, e o outro membro deverá responder ao bilhete de outro colega só que em registro formal. Desse modo, sempre haverá um colega da dupla que irá remeter o bilhete (scraps) e o outro que irá responder a outro colega, desde que não seja o bilhete remetido pela própria dupla.

Ao final do plano de aula, ressalva-se a função do professor como mediador das ações previstas na aula. Essa ressalva, em certo sentido, responde às discursividades que 
apregoam certa dispensabilidade do professor, quando do uso de tecnologias de informação e comunicação. Assim, reitera-se a importância do professor no acontecimento da aula, no processo de ensino e de aprendizagem.

Na seção "Tarefas dos alunos", são apresentadas setes tarefas de responsabilidade dos alunos. Essas foram conduzidas no plano de aula. Trata-se das ações que os alunos executariam em cada aula. Essa seção se mostra relevante para dimensionar as ações que os alunos precisam cumprir em cada aula, para que a aula aconteça. Em toda aula, o professor deve conduzir o aluno a formalizar as ideias, seja oralmente, seja por escrito. Vejamos abaixo as sete tarefas propostas.

1a - Os alunos deverão se reunir em grupo e pesquisar em sites de busca, através do laptop educacional ou telefone móvel as características e finalidades da carta, do bilhete, do convite e e-mail;

2a - Os alunos deverão debater sobre os gêneros pesquisados, e em seguida elaborar um conceito para os mesmos no fórum de uma comunidade do Orkut;

3a - Os alunos poderão confeccionar um cartaz sobre os tipos de correspondências estudados;

4a - Os alunos deverão assistir ao filme "Central do Brasil" e escrever sobre a importância do gênero carta como meio de comunicação entre pessoas;

5a - Os alunos deverão enviar uma mensagem SMS, através do telefone móvel, na linguagem informal, para um colega de sala e um e-mail na linguagem formal para a direção da escola, com cópia para o professor.

6a - Os alunos deverão enviar um convite para seus amigos (seguidores) através do twitter e, em seguida, ler para os colegas de sala;

7a - Os alunos deverão, em dupla, enviar um "bilhete" (scrap) para seu colega, através do Facebook, utilizando a linguagem informal. O outro membro da dupla deverá respondê-lo, utilizando a linguagem formal. (BRASIL, 2018, p. 5)

As sete tarefas propostas pautam-se no trabalho coletivo entre os alunos. Em todas as tarefas, sejam em dupla, sejam em grupo, o aluno é levado a praticar uma convivência e uma interação direta, de modo que a execução de sua tarefa está circunscrita ao(s) outro(s). Uma circunscrição ao pequeno grupo ou ao grupo maior. Além disso, até pela mediação das tecnologias, as tarefas levam a um trabalho de gestão do tempo: tempo de elaboração e de envio das mensagens, por exemplo; tempo de leitura e de resposta à mensagem recebida.

Outro aspecto que podemos ressaltar, dada a natureza das tarefas, é a possibilidade de promoção da participação e da colaboração entre os alunos. O efeito é diferente, se as atividades fossem tão-somente individuais. Não estamos esquecendo de que, a depender das características dos alunos, a resistência às atividades em dupla e/ou em grupo pode constituir-se em contingência ante o plano. O plano parte do princípio de que as tecnologias são familiares aos alunos e que, talvez por essa familiaridade, a participação e a colaboração sejam de outra natureza. No entanto, não há garantias sobre a futuridade da aula. 
A seção "para saber mais", traz a recomendação de leituras teóricas para o professor sobre os gêneros textuais enfocados nas três aulas planejadas. São recomendados dois textos disponíveis na internet. O primeiro texto é "Bilhete, carta, e-mail: os gêneros de comunicação pessoal na interação infantil", de Lúcia Helena Medeiros da Cunha Tavares. 0 segundo texto é "Gêneros textuais e a linguagem da internet", Everton Pereira Santos. Após cada texto recomendado, há uma sumarização deles.

A seção "Avaliação" apresenta um quadro em que cinco critérios são articulados a três níveis de desempenho (Avançado, Médio e Iniciante). Os critérios são, textualmente, os objetivos da aula, encabeçados pelo verbo "conseguir", flexionado na terceira pessoa do singular. Os dois primeiros critérios referem-se ao conteúdo dos gêneros textuais da área de Língua Portuguesa. Os outros três critérios concernem aos conteúdos das tecnologias de informação e de comunicação. Nessa seção, não está circunstanciado para o professor em que consiste a definição de "desempenho avançado", "desempenho médio" e "desempenho iniciante". Não aparece, também, o modo de como proceder nesse tipo de instrumento de avaliação.

A reivindicação deste procedimento não se refere a um "receituário" a ser seguido pelo professor. Trata-se, acima de tudo, de expor ao professor esse modo de mensurar o aprendizado. A avaliação do aprendizado, no espaço escolar, produz uma realidade, em termos de desempenho, para o professor e para o(s) aluno(s). É, por meio do método e das técnicas de avaliação, que os discursos do "rendimento escolar" ganham caução e, assim, certo efeito de objetividade.

Na seção "Exercícios de fixação", são apresentadas duas possibilidades de atividade. Essas atividades contam com o suporte virtual para a proposição. A primeira é um jogo virtual em que o aluno terá que marcar a resposta correta para a questão proposta. $\mathrm{Na}$ seção, aparece um print da primeira página do jogo. A segunda atividade é uma carta virtual em que o aluno precisará arrastar a possibilidade correta para preencher as lacunas. Essas possibilidades encabeçam a página virtual da carta. Ao final de cada atividade, aparecem as respostas.

Na seção "Exercícios para avaliação /// provinha Brasil • Prova brasil • Pisa e ENEM", aparecem cinco questões para serem trabalhadas com os alunos. São questões no formato das avaliações externas e que, possivelmente, cumprem a função de familiarizar os alunos com esse tipo de provas. Essas questões estruturam-se por meio de alternativas fechadas, com apenas uma opção de resposta. As duas primeiras questões tomam como ponto de partida o gênero textual "bilhete". As outras duas questões seguintes partem de um trecho do texto teórico "Gêneros textuais e linguagem da internet", possivelmente o mesmo utilizado na Seção "Para saber mais", já que a autoria não é indicada. A última questão toma dois exemplos de convites para demandar a diferença entre eles.

As cincos questões, até por estarem alinhadas ao modelo das avaliações externas, partem, de algum gênero textual para, em seguida, apresentar a questão. No caso das 
questões propostas, na seção em foco, a abordagem tematiza muito mais o formato do gênero textual. De nossa perspectiva, entendemos que não se trata de questões que levam o aluno a relacionar os saberes na funcionalidade do gênero textual. Não são questões que demandam uma leitura e uma compreensão mais elaborada dos textos, fazendo com que o aluno trabalhe sobre os conteúdos semânticos dos textos, por exemplo. No plano de aula, as alternativas corretas estão em vermelho.

\section{Considerações finais}

Ao longo deste artigo, filiados à perspectiva discursiva da Análise de Discurso, analisamos dois planos de aula que estão disponíveis em plataformas virtuais de livre acesso. É comum, na internet, a disponibilização e a circulação de muitos planos de aula prontos. É comum, também, o acesso e a tomada como modelo que professores em formação, no caso os estagiários dos cursos de licenciatura, fazem em relação a esses planos de aula. Muitos produzem o movimento de tomá-los como modelo sem necessariamente produzir certas reestruturações e problematizações. Na introdução, chamamos esses professores de "professores consumidores", pois suas posturas deflagram um investimento subjetivo aos planos de aula prontos para usar e consumir. Eles, na verdade, buscam planos de aula prêtà-porter, fazendo significar que bastaria um movimento aplicacionista do plano no espaço de sala de aula.

Na perspectiva discursiva, essa discursividade do "plano de aula pronto para usar e consumir", isto é, prêt-à-porter, está em relação de dominância em nossa sociedade capitalista neoliberal, na qual a tendência é significar tudo como mercadoria. Bastou acessar e imprimir o plano de aula para, em seguida, "aplicá-lo", em sala de aula. Nas disciplinas de Estágios Supervisionados Curriculares, a depender do acadêmico, essa discursividade o constitui sobremaneira. Na etapa de observação e de regência, o acadêmico precisa conceber a aula, em termos de planejamento, e, posteriormente, executá-la. Sendo assim, nessas disciplinas, a relação com o planejamento e com a elaboração de planos de aula se acentua e demanda uma postura autoral. Contudo, é comum a busca por esses planos de aula prontos.

Essa postura autoral é exigida tanto pela escrita acadêmica quanto pela complexa articulação entre teoria e prática (cf. AGUSTINI; LEITE, 2017). No caso do ensino de Língua Portuguesa, a proposição e o acontecimento da aula precisam estar alinhados a diretrizes, como: o ensino de Língua Portuguesa deve tomar os gêneros textuais como ponto de partida e de chegada; o ensino de gramática normativa não deve ser metalinguístico e, sim, epilinguístico; o eixo "prática de análise linguística" é um dos eixos norteadores da área de Língua Portuguesa. Essas diretrizes precisam ser operacionalizadas nos planos de aula de Língua Portuguesa, criando condições para que a aula de Língua Portuguesa aconteça. 
Assim, entre a proposição da aula, por meio do plano de aula, e o acontecimento da aula, no espaço escolar, consideramos que há uma contradição.

No sentido teórico, buscamos marcar a perspectiva de que essa passagem da proposição para o acontecimento da aula é marcado pela contingência. O tempo do planejamento e o tempo da execução deste pressupõe um ritual com falhas. E falhas, no sentido de que as projeções metodológicas produzidas se abrem ao diferente, ao heterogêneo, ao não previsto. Cada tempo, sob o imaginário que lhe ancora, possui especificidades. No decorrer deste artigo, ao analisarmos e problematizarmos dois planos de aula, abordamos a complexidade da proposição de um plano de aula, uma vez que, estando no tempo do planejamento, é preciso vislumbrar o espaço-tempo da aula. Trata-se de projeções que são produzidas com a matéria-prima ofertada pelo próprio tempo do planejamento. É o desdobrar-se no próprio tempo sem sair dele. Nesse sentido, as projeções metodológicas são uma função da escrita do plano de aula.

A oferta de planos de aula prontos em plataformas virtuais atende à demanda da educação como mercadoria, um mecanismo dos discursos neoliberais sobre a educação. Esses discursos em relação de dominância significam o professor como mediador e o destituem da função de construir com os alunos o saber, porque este, na condição de mercadoria, já está pronto para ser consumido tanto por ele, professor, quanto pelos alunos. Assim, nessa lógica de mercado, o saber desliza-se para uma questão de acesso à informação. Em meio a essas discursividades, a complexa articulação entre teoria e prática esvai-se, já que formação não é passível de ser transformada em bem de consumo; a formação é do sujeito, seja professor, seja aluno. A prática social de buscar planos de aula prontos apaga essa complexidade e promove sentidos de aplicabilidade. De nossa perspectiva teórica, torna-se mais problemático promover uma formação quando os sentidos dominantes são aqueles que apregoam a busca por capacitação. É a discursividade da capacitação que desloca a formação para o eixo das competências e das habilidades. Nesse mo(vi)mento discursivo, o plano de aula pronto é mais um bem de consumo a tomar parte do lugar do professor no processo de ensino.

Longe de professores consumidores de planos de aula prêt-à-porter, quando a questão é formação, são esperados professores que (re)elaborem e problematizem a complexidade existente desde o planejamento até o acontecimento da aula. São esperados, sobretudo, professores que tenham conhecimento para questionar as evidências que a lógica do funcionamento discursivo neoliberal (im)põe à educação. É necessário que a educação esteja além do capital para que a formação professoral aconteça. A proliferação de plataformas virtuais oferecendo planos de aula, provas, exercícios e outros prêt-à-porter ao professor só acentua a objetificação da educação. A oferta criada por certas discursividades capitalistas acabam criando a demanda. E, sob essa lógica, produz-se a fragmentação e a superficialidade da relação do professor com o seu objeto de trabalho: o conhecimento. Na esteira de Agustini e Rodrigues (2016), podemos salientar que esse tipo 
de disponibilização de planos de aula é um efeito do discurso neoliberal na educação, transformando a educação e as questões a ela relacionadas em mercadoria.

Para finalizarmos, é preciso destacar que, na formação inicial, a proposição e a execução do plano de aula indiciam o lugar de fala construído pelo professor em formação. Longe de ser um consumidor da educação prêt-à-porter, ele precisa assumir um lugar de fala, inclusive, para sustentar e para suportar a contingência do espaço da aula. Lugar esse da contradição constitutiva entre o tempo do planejamento e o tempo de seu acontecimento em sala de aula. Lugar em que a narratividade da experiência exitosa é constitutiva (cf. LEITE; AGUSTINI, 2018), mas é afetada por pontos de dispersão, demandando a (re)invenção constante desse lugar de fala.

\section{Referências}

AGUSTINI, Cármen; RODRIGUES, Eduardo Alves. O processo de (re)escrita de textos no espaço político-simbólico escolar: rasura, subjetividade, (neo)liberalismo. Revista Letras e Letras, edição especial, v. 32/3, p. 105-134, 2016. https://doi.org/10.14393/LL65v32n3a2016-7

AGUSTINI, Cármen; LEITE, João de Deus. A relação entre teoria e prática no Estágio Supervisionado em Língua Portuguesa: uma abordagem enunciativa. Revista ReVEL, edição especial n. 11, p. 158-181, 2016.

AGUSTINI, Cármen; LEITE, João de Deus. Da Experiência humana no Estágio Supervisionado em Língua Portuguesa. In: FIGUEIRA-BORGES, Guilherme; SILVA, Márcia Aparecida. Ensino de Línguas em diferentes contextos. Campinas, SP: Pontes Editores, 2017. p. 51-90.

BAKHTIN, Mikhail. Estética da criação verbal. Tradução a partir do francês de Maria Ermantina Galvão. 2. ed. São Paulo: Martins Fontes, 2000.

BRASIL. Ministério da Educação. Secretaria de Educação Fundamental. Parâmetros Curriculares Nacionais: Português (1으 e 20 ciclos do ensino fundamental). v. 3. Brasília: MEC, 1998.

BRASIL. Ministério da Educação. Diretrizes para a formação de professores da Educação Básica, 2001.

BRASIL. Plano de aula. Língua Portuguesa - Diferenciando correspondências. Disponível em http://portaldoprofessor.mec.gov.br/storage/materiais/0000016793.PDF. Acesso em: 12 mar. 2018.

DOLZ, Joaquim; SCHNEUWLY, Bernand. Gêneros orais e escritos na escola. Campinas, SP: Mercado de Letras, 2004. 278 p. (Tradução e organização: Roxane Rojo; Glaís Sales Cordeiro).

LEITE, João de Deus; AGUSTINI, Cármen. Dos relatos reflexivos do Estágio Supervisionado em Língua Portuguesa: a questão do regime enunciativo. Revista Signum. v. 21. n. 3, p. 346-366, 2018. http://dx.doi.org/10.5433/2237-4876.2018v21n3p346 
OLIVEIRA, João Batista Araújo; CHADWICK, Clifton. Aprender e Ensinar. São Paulo: Global, 2004.

PÊCHEUX, Michel [1975]. Semântica e Discurso - uma crítica a afirmação do óbvio. 4. ed. Campinas: Editora da Unicamp, 2009.

PÊCHEUX, Michel [1983]. Discurso - estrutura ou acontecimento. 5. ed. Campinas: Editora da Unicamp, 2008.

SBROGIO, Patrícia Cordeiro. Português - Jogo da memória dos pronomes. Disponível em https://educacao.uol.com.br/planos-de-aula/fundamental/portugues-jogo-da-memoria-depronomes.htm. Acesso em: 10 de mar. 2018.

Recebido em: 15/07/2018 Aceito em: 08/11/2018 